\author{
NBER WORKING PAPER SERIES \\ $\mathrm{ON}$ \\ HISTORICAL FACTORS IN LONG RUN GROWTH
}

\title{
CONJECTURAL ESTIMATES OF ECONOMIC GROWTH \\ IN THE LOWER SOUTH, 1720 TO 1800
}

\author{
Peter C. Mancall \\ Joshua L. Rosenbloom \\ Thomas Weiss
}

Historical Paper 126

\author{
NATIONAL BUREAU OF ECONOMIC RESEARCH \\ 1050 Massachusetts Avenue \\ Cambridge, MA 02138 \\ June 2000
}

The research reported here is part of the NBER' s program on the Development of the American Economy. This research is funded in part by the National Science Foundation (SBR9808516). Earlier versions of this paper were presented at McGill University, Queen's University, the University of Toronto, the University of WisconsinLaCrosse, and the conference "History Matters: Economics Growth Technology, and Population," held at Stanford University in June, 2000 . We thank the seminar and conference participants, especially Frank Lewis, for their helpful comments. We also thank Jasonne Grabher O'Brien and Maril Hazlet for their research assistance. The views expressed herein are those of the authors and not necessarily those of the National Bureau of Economic Research.

(C) 2000 by Peter C. Mancall, Joshua L. Rosenbloom, and Thomas Weiss. All rights reserved. Short sections of text, not to exceed two paragraphs, may be quoted without explicit permission provided that full credit, including (C) notice, is given to the source. 
Conjectural Estimates of Economic Growth in the Lower South, 1720 to 1800

Peter C. Mancall, Joshua L. Rosenbloom, and Thomas Weiss

NBER Historical Paper No. 126

June 2000

Development of the American Economy

\section{ABSTRACT}

This paper describes the first step in a larger project to build up regional estimates of economic growth before 1800 in the parts of North America that became the United States. In it we employ the method of conjectural estimation to develop new estimates of the rate of economic growth in the Lower South (modern day North Carolina, South Carolina, Georgia, and Tennessee) from 1720 to 1800 for both colonists and the Native American population of the region. Contrary to the widely held view that GDP per capita grew at a rate of 0.3 to 0.6 percent per year during the eighteenth century our best estimate is that per capita GDP grew at just 0.09 percent per year. Despite the slow growth of GDP per capita, however, the region's economy did achieve appreciable extensive growth, and achieving any advance in per capita production can be viewed as a significant accomplishment in light of the challenges that this growth posed for the economy. The difference between our estimate and those of previous studies appears to be the result of earlier scholars' undue focus on export performance. In contrast, our approach allows us to accurately account for the effect of the slowly growing domestic sector of the economy.

Joshua L. Rosenbloom

Department of Economics

University of Kansas

Lawrence, KS 66045

and NBER

jrosenbloom@ukans.edu

Peter C. Mancall

Department of History

University of Kansas

Lawrence, KS 66045

pmancall@ukans.edu
Thomas Weiss

Department of Economics

University of Kansas

Lawerence, KS 66045

and NBER

t-weiss@ukans.edu 
The economy of the British North American mainland colonies, so history and economics textbooks tell us, was a great success. Enterprising Europeans arrived in North America and, through hard work and the availability of land, they created a prosperous economy based on the export of agricultural staples. Yet despite wide acceptance of such a notion, scholars remain divided about the actual rate of growth in the colonies. ${ }^{1}$ The range of opinion on the speed of economic growth reflects the relative paucity of quantifiable data for the period before 1800 . In order to measure the colonial economy, it is necessary to employ a system of conjectural estimates originally propounded by Paul David (1967) and later employed by Weiss (1994) and Mancall and Weiss (1999)..$^{2}$

Subjected to such analysis, the early American economy no longer looks so successful. Based on the limited information available in published documents Mancall and Weiss (1999) concluded that there was little likelihood of economic growth in colonial America over the course of the eighteenth century. The rate of growth of GDP per capita was certainly less than 0.5 percent per year, and more likely was very sluggish, perhaps zero. Although Mancall and Weiss sought to present a picture of the most likely course of economic progress prior to 1800 , their primary purpose was to shift the focus of attention to the domestic economy and lay out a way of approaching its measurement, not to present the final word on the subject. ${ }^{3}$ They recognized that there were any number of ways in which those estimates might be improved upon. In particular, it seemed that the methods proposed would be better suited to examining subsets of the colonies, perhaps even

${ }^{1}$ McCusker and Menard (1985, pp. 52-57) argue that output per capita increased between 0.3 and 0.6 percent per year; Egnal (1975, p. 191-222) puts the growth at 0.5 percent per year between 1720 and 1775, while Jones (1980, p. 78) put it around 0.4 percent per year. Taylor (1964, pp. 427-44), however, asserts a much faster rate of 1.0 percent per year.

${ }^{2}$ David's conjectural technique was based on the work of Kuznets (1952).

3 The impetus for this shift was the 1995 Conference on The Economy of Early British America: The Domestic Sector, organized by John McCusker. 
individual colonies, and producing the aggregate picture by summing up its parts. Even if it turns out that the conjecture of no growth for the colonies as a whole is correct, the experience of each region could have differed widely. This would seem almost certain to be the case given the wide differences in the composition of the population and the disparate nature of each colony's economy, most especially the substantial differences in the magnitude and composition of foreign trade.

Here we present the results of our examination of one of those regions, the Lower South. ${ }^{4}$ Since this region was more heavily dependent on the export trade than any other region in the mainland colonies, historians have used exports as the key indicator of the success of the economy of South Carolina and its neighbors. ${ }^{5}$ But we need to set these assessments in a larger context by viewing the performance from the domestic side as well.

In order to measure the performance of the region's economy, we have made estimates of real gross domestic product per capita at four benchmark dates $1720,1740,1770$, and $1800 .^{6}$ Our findings demonstrate the impact of a large but relatively unprogressive domestic farm sector on the overall pace of economic growth. We find that during the colonial period, from 1720 to 1770 , the rate of growth of GDP per capita was positive but modest, averaging 0.09 percent per year. The rate of growth varied substantially within that time period. From 1740 to 1770 , the economy performed noticeably better as GDP per capita rose by nearly 0.4 percent per year, but in the heyday of export success, 1720 to 1740 , when exports grew by more than 6 percent per year in the

\footnotetext{
${ }^{4}$ For the colonial period this region is conventionally defined as including what would become the states of Georgia, North Carolina and South Carolina. Because one of our goals is to incorporate into our conjectures the economic activity of American Indians, we also include what came to be Tennessee. Its inclusion has little impact on any of our economic measurements for the colonists and their slaves because that state or territory was of little importance before 1800 except for its being the locus of economic activity by those Indians displaced from the colonies of the Lower South.

5 See Coclanis (1989) and Egnal (1998) among others.

${ }^{6}$ All figures are real dollars expressed in terms of 1840 prices. These estimates are similar in concept to the earlier conjectures made by David (1967), Weiss (1992 and 1994), and Mancall and Weiss (1999) in that the scope of coverage is consistent as regards the extent to which marketed and non-marketed output is measured.
} 
aggregate, the per capita value of GDP declined slightly from $\$ 55$ to $\$ 52$. And, in the period from 1770 to 1800 when exports per capita declined at a rate of 1.7 percent per year, GDP per capita rose ever so slowly at 0.08 per cent per year. The performance over the entire century was a bit better than Mancall and Weiss found for all the colonies and thus offers some support to the idea that exports helped to stimulate economic growth. The variations over time, however, make clear that exports were not always as powerful an engine of growth as some scholars have suggested.

Although we think these estimates depict the most likely rates of growth of the Lower South, they rest on a number of assumptions that leave open the possibility that growth may have proceeded at a different rate. In what follows we present our method for producing that best estimate and then examine the consequences of altering the most important assumptions on which it rests. We show that our estimate of a slow rate of growth in the long term is quite robust to these changes. We also show how the picture of economic growth in the region is changed if the economic activity of Native American Indians is taken into account.

\section{An Overview of the Lower South's Economic Development}

A generation of scholars has concluded that the Lower South and the Chesapeake were the most economically successful regions of British mainland North America. Both regions made extensive use of slave labor, had apparently successful staple-export sectors, and by 1774 had the highest levels of private wealth per capita in the colonies. ${ }^{7}$ Until recently, however, our knowledge about the Lower South did not go much beyond this. Writing in 1985, McCusker and Menard (1985, ch. 8) decried the lack of knowledge about this region. Since then, Peter Coclanis (1989),

\footnotetext{
${ }^{7}$ Much of their wealth was in the form of slaves. If measured by nonhuman wealth these regions were about equal to the rest of the colonies (Jones, 1980, p. 54).
} 
Joyce Chaplin (1993) and Marc Egnal (1998) and others have broadened our knowledge, but they still continue to focus on the export sector. When they reveal that not everyone lived in the low country, not everyone was a planter, and not everyone was engaged in foreign trade, they do not pursue the consequences for the region's growth implied by the wide variations in economic performance across these different spheres.

The conventional economic history of the Lower South has focused heavily on South Carolina, and especially the low country, for most of the eighteenth century. ${ }^{8}$ Such a focus makes some sense given the fact that colonists there were more heavily involved in international trade and the low country was home to some of the wealthiest British colonists in the Western hemisphere. North Carolina was more populous than South Carolina, but had far fewer slaves for most of the eighteenth century. ${ }^{9}$ Georgia, which was not established until 1732 and prohibited slavery until 1749 , was a relative latecomer, and contained only a small fraction of the region's population. The economic history of South Carolina, and indeed of the region, consists of two distinct stories: one for the low country and a second for the back country. Historians, however, have focused predominantly on the development of staple agricultural production, which was confined primarily to the low country until the introduction of short-staple cotton in the mid-1790s. To be sure, exports-especially of rice-were substantial. ${ }^{10}$ In 1700 , rice exports totaled only 450 thousand

${ }^{8}$ McCusker and Menard devote almost their entire discussion on the Lower South to South Carolina, while North Carolina and Georgia are mentioned only in passing (1985, chap. 8).

${ }^{9}$ North Carolina's share of total regional population fell from around 65 percent in 1700 , to about 50 percent at the end of the century, while South Carolina's share of regional population rose from 35 percent in 1700 to a peak of 50 percent in 1730, before falling back to around 35 percent at the end of the century. Slaves, however, made up a much larger share of South Carolina's population - constituting a majority for most of the eighteenth century. As a result, South Carolina contained 85 percent of the region's slave population in 1700, and although the numbers of slaves in Georgia and North Carolina grew more rapidly than those in South Carolina, at the end of the century it still accounted for 43 percent of the region's slaves (U.S. Bureau of the Census 1975, Series A-7, and Z-1 to 19).

${ }^{10}$ Cattle raising, production of naval stores, and the deerskin trade were also important activities. Menard (1996, p. 275); Dethloff (1982, p. 233); Clifton (1981, p. 274); Nash (1992, pp. 679-81). 
pounds, but by 1720 they amounted to 6.5 million pounds and continued to climb, reaching a temporary peak of 43 million pounds in 1740. This initial period of expansion was brought to a sudden end in $1740 .{ }^{11}$ At nearly the same time international conflicts substantially raised shipping and insurance costs and restricted the market for rice. Slave imports also fell precipitously, dropping to only a fraction of their level in the previous decade. The depressed conditions persisted for most of the decade. During the 1740 s, planters experimented with other crops, including indigo, which emerged as an important complement to rice. ${ }^{12}$ By 1748 , indigo accounted for $10.4 \%$ of South Carolina's exports, putting it third in importance behind deerskins $(22 \%)$ and rice $(55 \%)$. With the return of peace in the late 1740 s, rice prices recovered along with exports, and the importation of slaves resumed. In the early 1760 s, rice prices began to increase again, and exports shot upward in the decade and a half before the Revolution (Nash 1992, p. 692; Dethlof 1982, p. 235). During this export upsurge planters expanded rice cultivation into Georgia and the Cape Fear region of North Carolina. But despite the expansion, South Carolina remained by far the largest producer.

The upward trajectory of rice exports came to an end with the American Revolution.

Material losses during the war were substantial due to the sustained conflict in the region. ${ }^{13}$ The devastation caused by the war is apparent in the low levels of exports in the immediate post-war period. Exports rose rapidly in the second half of the 1780s, but even at their peak in 1793 ,

11 In 1739, the Stono slave rebellion contributed to the colonists' fears about the growing majority of AfricanAmericans in the colony, and resulted in the passage of a prohibitive duty on slave imports which lasted until 1744 (Richardson 1991, p. 131; Crouse 1977, p. 56; Wood 1974, p. 325 ).

12 British bounties made the crop commercially attractive, and because it was less bulky than rice, it was less affected by the wartime rise in shipping costs. Moreover, since it could be grown on lands not suited to rice cultivation, and its peak labor demands did not coincide with those of rice cultivation, planters could add indigo without substantially reducing their commitment to rice (Gray 1958, p. 289).

${ }^{13}$ Perhaps the most important effect was the reduction in the slave population occasioned by the war. The conflict interrupted the importation of slaves, and resulted in significant losses to the existing slave population. Although data are imprecise, it is estimated that approximately 25,000 slaves died, ran away, or were carried off by the British during the war (Morgan, 1983, p. 111; Gray, 1958, p. 596) 
Charleston's post-war exports were well below the level of the early 1770s (Gray 1958, pp. 102023).

The robust, export-based growth of the low country economy in the decades prior to the Revolution coincided with the rapid expansion of settlement into the interior of the region. For the most part, the settlement of the back country consisted of small independent farmers possessing few if any slaves, and producing only small quantities of marketable crops (Hughes 1985; Johnson 1997, pp. 40-60; Klein 1990, pp. 10-27). As late as 1770, only 6,000 (8.7 percent) of South Carolina's 76,000 slaves lived in the back country. In contrast, 30,000 (61 percent) of the colony's 49,066 free inhabitants resided in this region and they were virtually unconnected to the export trade dominated by the low country. ${ }^{14}$ Over the next 20 years, the back country's share of both free and slave population increased, the latter having risen by nearly 400 percent, growing to slightly more than 29,000 by 1790 and accounting for 27 percent of the state's slave population. ${ }^{15}$ Although this shift of the population set the stage for the ascendance of cotton at the end of the century, rice planters remained the dominant employer of slaves.

In contrast to South Carolina, the economic histories of Georgia and North Carolina remain relatively unexplored. Georgia got a late start, and a disappointing one to its founders, but after the prohibition on slavery was lifted its economy grew more quickly. Its success paralleled that of South Carolina's, and by the end of the colonial period it too could boast of being home to some of the wealthiest colonists in British America (Chaplin, 1993; Egnal, 1998, p. 99). Unlike its southern neighbors, North Carolina had only a small export sector. Although the colony exported some naval

${ }^{14}$ In 1768-72 average annual exports per capita in Carolina's low country averaged 3.7 pounds Sterling for the entire population, and a whopping 17.11 pounds for the white population. The back country figure was a mere half pound (Coclanis 1989, p. 75).

15 The rapid expansion of cotton cultivation beginning in the early 1790 s perpetuated this shift, so that close to 44 percent of the state's slaves were living in the back country in 1810. 
stores, tobacco and wheat, for the most part its economy resembled that of the back country of South Carolina (Egnal, 1998, 114-117).

Although the disparities between colonies and regions have been pointed out by other scholars (see, e.g., Chaplin, 1993, pp. Coclanis 1989, pp. 75-76; Egnal 1998, p. 117), their implications for the course of economic growth have not been pursued in previous discussions of the region's economic history. Exports benefitted only a minority of the region's population. Slaves never reaped any of the fruits of this success, of course, but export-based success also escaped the majority of the free population. To understand the contours of the entire economy, we need to look beyond the low country rice exports. We need, that is, to assess the contributions of every sector of the southern economy, including the non-staple agricultural segments.

\section{The Method}

The measurement of a nation's or region's aggregate output, such as gross domestic product, is one way in which all aspects of the economy can be taken into account. Such statistics add up the output of the dynamic sectors as well as the sluggish ones and present a composite view of the economic activities. There are no such national income statistics available for the colonies, nor is there enough evidence to compile the sort of national income accounts that have been prepared for the nineteenth century. To circumvent this paucity of data, we have used the conjectural method of estimation to produce approximations of the Lower South's gross domestic product. ${ }^{16}$ Gross

\footnotetext{
16 An alternative measure would be gross national product. The difference between domestic product and national product amounts to the net balance of factor payments to and from foreign nationals, which for most of American history has not been very large. For the colonial era the differences are likely to have been larger and their size would depend on which population was thought of as the national one. The value of either measure would depend to a large extent on how one treated Indians and their output, and, because Indians made up a much larger portion of the population in 1700 than in 1800, the divergence between domestic and national product would have been larger at the earlier date.
} 
domestic product (GDP), as commonly defined, measures the value of output produced within the domestic economy regardless of the ethnic background or nationality of the people involved in producing it. ${ }^{17}$ Because we are interested in gauging the importance of the economic activity of Native Americans, and because their residences were located more widely and changed more often than those of the colonists and their slaves, we have defined the region broadly to include Tennessee where many Cherokee resided.

Like conjectures about the early nineteenth century by David (1967) and Weiss $(1992,1994)$, those we report here should not be given the same status as estimates prepared today by national income accountants or the extensions backward into the nineteenth century by Kuznets (1946) and Gallman (1966). Our work is best viewed as a quantitative experiment about the likely course of economic progress, rather than a precise estimate of the course of real aggregate product. In order to generate estimates of aggregate output we have had to resort to using some average figures and stylized facts. The values selected for some variables may not have occurred in the specific year to which we refer, perhaps not in any year, but should represent what likely occurred, on average, around the time of each benchmark date. Those likely values and trends enable us to establish a baseline performance for the region that can then be used to conduct experiments using other values for selected variables.

We have generated separate estimates of output produced by the Native Americans and that produced by the colonists and their slaves. The latter figure is more akin to the measure that has been used in previous discussions of the period, and is the chief focus of our empirical work. The

\footnotetext{
17 The "economy" is commonly defined by the geographic boundaries of the country, but it is subject to other interpretations and has been applied differently in some instances. See for example Metzer (1995) and Butlin (1986). For the colonial period it is difficult to speak strictly of domestic or national product because geographic boundaries were ambiguous and fluid, and the British and Indian populations resident in the Lower South were citizens of other nations.
} 
estimate of production by Native Americans is more experimental, but provides illuminating results, especially when combined with the estimate for the non-Indian population. As Mancall and Weiss did in an earlier work, we refer to this more comprehensive figure as a "multicultural" estimate. ${ }^{18}$ Because of the difficulty of disentangling some economic activity of Native Americans from that of the colonists, we believe this multicultural estimate is a more reliable gauge of aggregate production than is either of the separate estimates.

We report here on the estimates of GDP per capita that exclude the value of home manufacturing and farm improvements. ${ }^{19}$ GDP is the sum of the conjectured values of the output produced in three sectors: agriculture, housing, and nonagricultural industries. ${ }^{20}$ We obtained those values by following the procedures laid out by David. Because the estimation proceeds backward in time - that is, we take the values available for each of the components in the base year of 1800 (1770 in some cases) and then extrapolate them backwards to earlier years - the base year figures take on added significance. ${ }^{21}$ It is these known pieces of information that set bounds on the growth that could have occurred over the preceding century. ${ }^{22}$ These base year values are summarized in Table 1, which also includes data for the nation as a whole in 1800 from Mancall and Weiss (1999) to permit comparisons with the region.

18 Butlin (1986) coined this the term to describe the estimates he prepared for Australia.

19 The exclusion of these unconventional items is not as serious a matter as it might appear. We have not excluded these items because they were unimportant, but rather because they were likely more important in 1720 than in 1800. Their inclusion would raise the level of GDP in all years, but more so in 1720, and would thus bias downward the estimated rate of economic growth.

${ }^{20}$ Nonagricultural output, other than the value of shelter, encompasses a wide variety of items: the value of manufactured goods (including those exported), investment, as well as services, including the value of government services.

21 These 1800 figures are in effect known values. They are not known with the precision or completeness of official statistics, but they were taken from existing work and were not generated by our conjectures.

22 The GDP per capita figures in 1800 for the region were based on the national estimates by Weiss (1992, Table 1.4). David's (1967) estimates for 1800 are lower than Weiss's and would thus dictate less growth for the preceding century. In both cases, the figures were conjectured in ways that leave the 1800 figures unbiased by business cycle influences that may have occurred. 
In order to extrapolate the 1800 value of GDP per capita to earlier years we followed the method espoused by Paul David. Output per person (GDP/P) in any year equals the product of two input values, namely the participation rate $(\mathrm{LF} / \mathrm{P})$ and a weighted average output per worker; which equals output per worker in agriculture (a) and nonagriculture (n) weighted by each sector's share of the labor force. ${ }^{23}$

$$
\mathrm{GDP} / \mathrm{P}=(\mathrm{LF} / \mathrm{P})\left[\mathrm{S}_{\mathrm{a}}(\mathrm{O} / \mathrm{LF})_{\mathrm{a}}+\mathrm{S}_{\mathrm{n}}(\mathrm{O} / \mathrm{LF})_{\mathrm{n}}\right]
$$

In the absence of time series evidence on output per worker in the nonagricultural industries, David assumed that productivity there grew at the same rate as it did in agriculture. As a result, at any point in time $\mathrm{O} / \mathrm{LF}_{\mathrm{n}}=\mathrm{k}(\mathrm{O} / \mathrm{LF})_{\mathrm{a}}$, where $\mathrm{k}$ is the ratio of sectoral productivities in some given year. With that modification, and the fact that $S_{n}=\left(1-S_{a}\right)$ the equation becomes.

$$
\mathrm{GDP} / \mathrm{P}=(\mathrm{LF} / \mathrm{P})\left[\mathrm{S}_{\mathrm{a}}(\mathrm{O} / \mathrm{LF})_{\mathrm{a}}+\left(1-\mathrm{S}_{\mathrm{a}}\right) \mathrm{k}(\mathrm{O} / \mathrm{LF})_{\mathrm{a}}\right]
$$

As can be seen, very little information is needed and changes in GDP per capita arise from only three things: changes in the participation rate, changes in agricultural output per worker, and shifts in the distribution of the labor force out of agriculture.

We have modified this equation in two respects. First, we have allowed nonagricultural productivity to increase faster than agricultural productivity by specifying that the ratio of the former to the latter (i.e. the value of $\mathrm{k}$ ) rose over the period.. Second, we have treated shelter as an independent sector, rather than subsume it in either agriculture or nonagriculture. We have done so because we did not want the value of shelter output to influence the calculation of output per worker in either of the other sectors. Although shelter output arose in both agriculture and nonagriculture,

\footnotetext{
${ }^{23}$ David used the input values to calculate an index of output per capita in each benchmark year that was then used to extrapolate the base year's (1800) dollar value of GDP per capita to each of the earlier years, but one can solve the equations directly.
} 
in neither case was it produced directly by labor. Our estimating equation is:

$$
\mathrm{GDP} / \mathrm{P}=(\mathrm{LF} / \mathrm{P})\left[\mathrm{S}_{\mathrm{a}}(\mathrm{O} / \mathrm{LF})_{\mathrm{a}}+\left(1-\mathrm{S}_{\mathrm{a}}\right) \mathrm{k}_{\mathrm{t}}(\mathrm{O} / \mathrm{LF})_{\mathrm{a}}\right]+\left(\mathrm{O}_{\mathrm{s}}\right)
$$

In order to solve this equation for each of our benchmark years we need information on four items: the population; the labor force, and its distribution between agriculture and nonagriculture; the values of agricultural output, including exports, and the value of $\mathrm{k}_{\mathrm{t}}$. David had available to him estimates for each of these, although he did make some improvements and modifications to them. ${ }^{24}$ We have had to construct each of these series, except that for total population. ${ }^{25}$

\section{Labor Force Estimates}

The labor force series was derived by using the procedures set out by Lebergott (1966) and Weiss (1992) to produce estimates for the nineteenth century. The total labor force is the sum of the estimates of the number of free male workers, free female workers, male and female slave workers, and male and female Native American Indian workers, all aged 10 and over. ${ }^{26}$ The labor force in each population category is the product of the estimated population in that category and an assumed labor force participation rate. $^{27}$ We estimated the agricultural labor force as the product of the rural population aged 10 and

\footnotetext{
${ }^{24}$ David had evidence on three of the four, and for lack of time series evidence on sectoral productivities assumed a constant ratio based on the evidence for 1840 .

${ }^{25}$ The free and slave population figures were available in Historical Statistics, series Z15-19, McCusker and Menard,1985, p. 182, and Coclanis, 1989, p. 64; the Native American population figures come from Wood, 1989, pp. 38-39. We had to estimate the age and sex distributions. The evidence we have found for the colonies of the Lower South indicates the share of the free and slave population that was aged 10 and over, and thus more likely in the labor force, declined over time; from around 69 percent in 1720 to 63 percent in 1800 for the free population and from 79 percent to 68 percent for slaves. The share of native American Indians aged 10 and over appears to have been constant. See Chaplin 1993, Klingberg 1939, Menard 1995, Morgan 1983, Wood 1974, and Weiss 1992.

${ }^{26}$ The figures for 1800 included separate estimates for free males and females aged 10-15 and those aged 16 and over (Weiss, 1992).

27 The participation rates were those specific to the Lower South in 1800 (Weiss, 1992). Although we assume that these rates were constant over time for each population component, because the rates differed across the components, the average for the entire population changed over time.
} 
over and a specified rural agricultural participation rate plus a similar estimate for the urban population. The rural agricultural participation rates were based on the evidence for the nineteenth century. We assumed that those rates declined for all workers over the course of the eighteenth century at the same rate they changed for free workers in the first half of the nineteenth century. We believe this imparts a noticeable bias to the changes in the agricultural labor force, in effect slowing down the growth of the farm labor force which in turn biases upward our measured growth in output per worker and thus output per capita as well.

\section{Agricultural Output}

We estimated the value of agricultural output as the sum of food that was produced for consumption within the colonies (f), firewood (w), and those agricultural products that were exported (x). The food produced for consumption within the region (f) equals the food consumed (c) less the value of any imports of food (m). Agricultural exports can be divided into those shipped $\operatorname{abroad}\left(\mathrm{x}_{\mathrm{f}}\right)$ and those shipped to other colonies $\left(\mathrm{x}_{\mathrm{c}}\right)$. We treat all this agricultural output as though it were marketed in order to place a value on it and to make our estimates comparable in scope to those for the early part of the nineteenth century.

The dominant component of agricultural output in the colonies was food, and regrettably there is no time series data on this item for the eighteenth century. Its production can be approximated, however, by the value of consumption if allowance is made for the import and export

of food items. Although there is no time series evidence on consumption, we believe there is enough information about the diets of colonists and slaves to permit a reasonable approximation of the likely values of food consumed.

Existing documents provide evidence on the diet or its components, and on the value of 
providing a specified diet for a number of different groups in the population: free settlers, soldiers, slaves, prisoners, charity cases, and so on. The evidence comes from a variety of sources, such as official colonial records, court cases, committee hearings, travelers' accounts, plantation records, and vestry minutes. The records of the Trustees of Georgia, for example, contain well-documented evidence on the monthly costs of maintaining those persons sent over to the Colony, and reported as well the standard provisions for maintenance of settlers. ${ }^{28}$ The specified diet included beef or pork, rice, peas, flour, beer, molasses, cheese, butter, spice, sugar, vinegar and salt. Moreover, the different quantities of each were specified for adult males, adult females, children and servants. ${ }^{29}$ The colonial records for Georgia and South Carolina also reported expenditures on provisions for troops, including in some instances slaves and Indians. ${ }^{30}$ The evidence from South Carolina for the period 1734 to 1756 indicates that the value of provisions provided to soldiers declined over time regardless of whether it is valued in South Carolina currency, Pounds Sterling, or Dollars (in prices of 1840$).{ }^{31}$

Vestry minutes are another rich source of evidence on weekly, monthly and annual maintenance. ${ }^{32}$ Those for St. Helena's Parish in South Carolina and St. Paul's Parish in Chowan

${ }^{28}$ Candler (1904-1916, vol III). The amounts expended after the first year or two appear quite high and would suggest that the value of the diet declined between the 1730s and 1800. We believe that some of the provisions must have been destined for settlers who had gone over in earlier years, and thus think the initial year's figure may be a better approximation of the average value of the diet.

${ }_{29}$ We have valued this diet at $\$ 28$ per adult male in prices of 1840 . The diet for women and children aged 12 and over was calculated to be 83 percent that of a male; that for children aged seven to twelve was specified be half that for those aged 12 and over; and that for those aged two to seven was one-third. Apparently no provisions were provided for those under two years of age. (Candler 1904-1916, vol. III, 408-09).

30 See for example the expenditures for Oglethorpe's siege of St. Augustine (Candler 1904-1916, vol. II, 159202. Gallman (1971 pp. 71-78) argued that military rations seem like a reasonable proxy for food consumption by the colonists.

31 The figures, converted to dollars and valued in 1840 prices, were $\$ 32$ in 1734 declining to $\$ 22$ in 1756 . It may be that the soldiers were expected to obtain some of their provisions by hunting and fishing, and perhaps increasingly so over time as suggested by the decline in the allotment after 1736 (CRSC, vols. 1, 2, 7 and 14). 32 Vestry minutes are the records of the church parishes. Parishes had the primary responsibility for the care of the poor and could levy taxes to finance their activities. See Brown (1928) and Watson (1977). 
County, North Carolina, for example, cover a long span of time. The expenses reported for maintaining wards of the church reflect the deliberations of those on the scene familiar with the standard of living in the vicinity and the costs of providing for it (Salley, 1919 and Fouts, 1999). Moreover, in many instances the wards appear to have been regular members of the church—friends and neighbors of the vestrymen — not outsiders to the parish. Indeed in some cases the wards were relatives of those who were providing the funds. The evidence from St. Helena's parish is sparse, but the minutes from St. Paul's Parish contain over 200 entries about the provision of maintenance. Over the entire period covered, there appears to have been very little change in the average allowance. ${ }^{33}$ This seems most evident in the allowances made for terms of six months or longer. The evidence also indicates that the allowance for children ran between one-half and two-thirds that of an adult.

Finally, we have data on the quantity of corn included in probate inventories for 1732-38 and 1772-75. ${ }^{34}$ There are difficulties in interpreting this information since the stocks of corn varied from quarter to quarter and year to year. The average for the first and third quarters of each year suggests that corn inventories per person rose slightly between the 1730s and the early 1770 s, while the evidence for the second and fourth quarters indicates the stocks fell noticeably over time. If these inventories represent the changes in food production that had been taking place, then it does not appear that there was any sustained increase in production per person over time.

Information on the slave diet is scarcer, making assessments about changes in the diet over time especially frustrating. ${ }^{35}$ It may very well be that there was little change in the slave diet. After

33 The evidence from St. Helena's parish suggests little change in the weekly rate whereas the annual figure for longer term arrangements rose from around \$12 in 1738 to $\$ 45$ in 1773.

34 These data come from an examination of all inventories collected by Chaplin (1993) containing corn in the specified periods.

${ }^{35}$ Morgan (1998, pp. 135-43) argues there were differences in slave diets across regions, and slaves in the low country produced more food on their own time than did those in the Chesapeake. His evidence, however, does not suggest much about changes over time. 
all, it was not highly varied in the nineteenth century and the quantities of food planters provided had to be sufficient to provide for the calories and protein necessary to carry out the arduous work of producing rice or indigo. In the nineteenth century, the value of a slave's diet equaled about 75 percent that of a free person. The information we have found for the colonial period would put the relative value anywhere between 20 percent and 75 percent. ${ }^{36}$ In other words, the value of the slave diet may have risen substantially or remained constant over the eighteenth century.

Based on this evidence, we believe that the diet of free colonists did not change much, if at all, over the course of the eighteenth century. It no doubt had its ups and downs with the state of the harvest and with the booms and busts of the economy, but the underlying trend value must have been rather steady. Therefore, we have assumed in our baseline conjecture that the value of an adult colonist's diet did not change from 1720 to 1800 . The evidence is even more clear that the diet of a slave differed from that of a colonist, and that of an adult colonist differed from that for a child. ${ }^{37}$ We have assumed that the value of a child's diet remained at 50 percent of an adult's diet for the entire century. ${ }^{38}$ In estimating the diet of a slave, we argue that its value increased from around 50

\footnotetext{
${ }^{36}$ CRSC II, Commons Journal, 1739-1741, p. 493 and CRSC IV, Commons Journal,1742-1744, p. 377. The relative value of 20 percent seems too low. The figures lying behind that ratio imply annual values of $\$ 46$ for a free person and $\$ 9$ for a slave (in prices of 1840). The value seems very low for slaves and high for free persons, thus yielding much too low a relative figure for slaves.

37 The value of food consumed per capita is thus a weighted average of the value consumed by the colonists and that consumed by the slaves, and the average for the colonists is a weighted average of that consumed by an adult and that consumed by a child, where the weights are their respective shares of the population.

${ }^{38}$ If instead we had assumed that the child's diet had equaled 75 percent of an adult's, food consumption and production per capita would have been $\$ 3$ to $\$ 4$ higher in each year, but growth would have been about the same.
} 
percent of a colonist's diet in 1700 to 75 percent in $1800 .{ }^{39}$ With these assumptions we have calculated the value of food consumed at each benchmark date.

Although international trade data are more abundant, as would be expected given the nature of the relationship between the colonies and Great Britain, the coverage is not comprehensive for the earlier years of the colonial era or for the period from 1772 through 1790. Moreover, we wanted a series on only domestically-produced agricultural exports, and not one that included re-exports. We constructed the desired series in constant prices by first establishing a benchmark of agricultural exports from the Lower South to all countries in 1770 and then extrapolating that latter figure back to 1710 on the changes shown in a series representing the volume of trade. ${ }^{40}$ The trade figures for 1800 were calculated from statistics presented by Pitkin (1816, reprinted ed.1967, Table II, p. 54) and North (1961, Table B-III, p. 221 . Pitkin reported total exports (including re-exports) by state for the years 1791 to 1810 , and domestically produced exports by state from 1803 to 1810 . North reported national data for both total exports and re-exports for the entire period 1790 to 1810 . We used the ratio of domestically-produced to total exports by state for 1803-10 and the change in the domestically produced share for the nation from 1790-1803 to estimate the value of domestically produced exports from the Lower South in 1800.

The estimate of food imports from and agricultural exports to other colonies for 1770 comes from Shepherd and Williamson (1992, Table 2). ${ }^{41}$ We used statistics on tonnage entering and

\footnotetext{
39 We based this beginning year value on Kahn's estimate for the "least-cost diet with minimum fat requirements" which amounted to $\$ 23.43$ (in 1860 prices) using the medium price of pork. (Kahn, 1992, table 25.5 , p. 532). That estimate equaled approximately 75 percent of the cost of the diet specified by Fogel and Engerman or Sutch, which in turn was equal to 75 percent of the cost of a free person's diet. Thus we assumed that the value of the slave diet in 1800 equaled 75 percent that of a free person, and the value in 1700 equaled 75 percent of that 1800 figure-i.e., 56 percent of a free person's diet — and that it changed at a constant rate between those two dates.

40 The volume index of trade was based largely on the work of Nash, 1992, but we enhanced his series by taking into account the export of tobacco.

41 We assumed that the 1800 value was equal to that for 1770 .
} 
clearing Charleston (Clowse, 1981, Table C-11) to estimate the value of food imported from and the value of agricultural exports to other colonies at eight dates between 1717 and $1768-72$. We assumed that the real value of intra-colonial shipments comprised the same share of all shipments (foreign and coastal) at each of those dates as they did in 1770. In order to obtain the value for the specific benchmark dates shown in Table 2 we interpolated between the nearest years for which we had estimates.

With the addition of an estimate of the value of firewood produced we obtain the value of agricultural output for the region. ${ }^{42}$ These figures are shown in Table 2.

\section{Shelter}

Per capita values of shelter in 1800 of $\$ 4.80$ for free persons and $\$ 0.60$ for slaves were derived from the value of dwellings reported in the tax inventories of 1798 (Soltow 1989, table 10) and an assumed annual flow of shelter services from that stock (Gallman, 1966). These figures were weighted by the respective population shares to obtain the figure shown in Table 1 for the non-Indian population in the Lower South. ${ }^{43}$ Because those figures were calculated as the product of the stock of dwellings and an annual flow of housing service emanating from that stock, we used an index of change in the stock of dwellings to extrapolate the 1800 figure backward to 1700 . We based the index on Jones's estimate of the rate of growth of wealth per capita between 1700-25, 1725-50, and 1750-74, and Gallman's estimate of the rate of growth of the real value of structures between 1774

\footnotetext{
42 The evidence on firewood consumption came from a government report. Although one may be skeptical of the exact figures on fuel wood consumed, the trend in the series should be reasonable. The estimates were made on a regional basis and the underlying per capita consumption rates tried to "take into consideration the climate, the timber, the characteristics of the population, housing conditions, the shift from fireplaces to stoves, and the displacement of wood by mineral fuels" (United States Department of Agriculture 1942, table 2).

43 The figure shown for the U.S. in Table 1 is the earlier estimate used in Mancall and Weiss (1999).
} 
and 1799 (Jones 1980, p. 78; Gallman 1992, p. 95). In effect we have assumed that the dwelling share of wealth and of structures remained constant over the period.

\section{Empirical Results}

The results of our conjectures are shown in Table 3. We have focused on the period beginning in 1720 because that date seems to best divide the region's history into an early period of experimentation and adjustment and the subsequent period based on rice exports. Further, for the post-1720 period we have more reliable and complete statistics on some of the key variables that make up our conjectures. We have presented statistics for only four benchmark dates and focus on the likely trend values. By doing so, we avoid the impression that we have constructed a complete series on colonial GDP. Even with only these four points the results are very illuminating.

The most noteworthy result is that the conjectured trend in real GDP per capita (narrowly defined) reveals growth of only 0.09 percent per year over the colonial period (1720-70) as well as over the entire period 1720 to 1800 . GDP per capita rose by $\$ 4$ over the eighty years. ${ }^{44}$

Within the colonial period the region experienced particular success between 1740 and 1770 . During that period, agricultural exports abroad were a positive force as they rose 3.8 percent per year in total. This was not much faster than population growth, however, with the result that the per capita value of exports abroad rose by only 0.16 per cent per year. Neither did shipments of

\footnotetext{
${ }^{44}$ These results look only at production within the region and not at the level of consumption that this would provide (except of course for the all-important consumption of food). Because some amount of the output was exported, the consumption that could be acquired with those exports would have varied with changes in the terms of trade. There are of course problems with measuring the terms of trade, perhaps especially for a region for which one of the most important imports was slaves. Nevertheless, we have constructed a terms of trade index and it shows very little change over the entire period. As a result if we adjust the value of exports by the terms of trade and calculate a trade-adjusted GDP series, it would rise by about the same amount as the unadjusted series over the entire period 1720 to 1800 . As discussed below, the effect is more noticeable in some time periods, especially $1720-40$.
} 
agricultural products to other colonies change much on a per capita basis over that period. GDP per capita was boosted by the domestic sector, by the production of food and firewood (see Table 2). The former rose by more than $\$ 2$ per capita and the latter by $\$ 1.60$. Food production increased because the region substituted domestic production for importation from other colonies. We estimate that the value of food imported from other colonies declined by $\$ 1.75$ between 1740 and 1770.

That performance contrasts sharply with the previous twenty year's record. Between 1720 and 1740, exports abroad surged; having risen by 6.2 percent in the aggregate and 0.5 percent per year on a per capita basis. Growth of GDP per capita was held in check by the slow growth of the food and firewood producing sector. The latter did not change on a per capita basis, while the former declined by about $\$ 3$. That decline reflects the lower amount of food being consumed in the region because of the increase in the slave share of the population with their lower consumption standards, but also because the region appears to have imported more of the food that was consumed. The per capita value of food imports from other colonies rose by $\$ 2$ between 1720 and 1740. Thus some of the growth of exports abroad was accomplished by shifting resources out of the production of food for the local market. The net result of these offsetting forces was negative; GDP per capita declined at 0.3 percent per year. When the terms of trade are taken into account, the performance looks better. We estimate that the terms of trade became more favorable between 1720 and 1740 , by about 25 percent, and that GDP adjusted for the terms of trade declined by only 0.18 percent per year.

The performance in that period of great export success indicates the extent to which the slower-growing food and firewood producing part of the agricultural sector could influence the overall rate of growth. In subsequent years the food producing sector was less of a drag, and had 
the export sector been able to maintain its rapid pace of growth, or if it had slowed down less than it did, the region's economic history might have been much different; it would have been a phenomenal success story. Such was not the case. Export growth slowed so much that the per capita value of exports grew very little between 1740 and 1770, and then declined after 1770. In those circumstances, the region was fortunate to have had the larger, slower-growing food and firewood producing sector which plowed ahead steadily.

Clearly any picture of colonial success that rests on the performance of the export sector alone is likely to misrepresent the true course of change. This should not be too surprising. Exports were a relatively small part of the economy. They have received a great deal of attention because they were the raison d'etre for British colonization, they were at the heart of political debate, and statistics have been readily available. Moreover, exports from the region grew quite rapidly in the aggregate — rising at nearly 4.0 percent per year between 1720 and 1800 — so that sector would appear to have been dynamic and capable of generating sustained growth. Population, however, was simply growing quicker, in excess of 4.0 percent per year for the entire period.

Changes in the value of food exports to and imports from other colonies appears to have influenced the timing of economic growth. Our estimates indicate that changes in these items had little bearing on the long term rate of economic growth, but fluctuations in those values, especially in the import of food from northern colonies, affected the pace of growth in specific subperiods. If we assumed there had been no intra-colonial trade, growth over the long term would have been only slightly higher (0.13 percent per year from 1720 to 1770 and 0.11 from 1720 to 1800$)$. Over the period 1720 to 1740 , however, GDP per capita would have held steady at \$54 instead of having declined as indicated in our conjectures. On the other hand, growth over the period 1740-70 would have been slower, only 0.24 percent per year instead of the 0.37 rate shown in our baseline 
conjectures. Clearly the role of intra-coastal trade deserves further investigation. ${ }^{45}$

Lying behind the growth in GDP per capita that had occurred were noticeable rates of increase in output per worker, especially after 1770 when output per worker went up by 0.65 percent per year. Over the longer term our estimates of agricultural output and the labor force engaged therein yield growth of output per worker of nearly 0.32 percent for the entire period 1720 to 1800 , and 0.11 percent for the colonial period. ${ }^{46}$ By assumption, the rates of growth of nonagricultural productivity were slightly higher. The reason why such rapid productivity growth did not translate into more rapid growth of output per person is fact that the labor force was declining relative to the population, especially after 1770 . This reflects three things: the changing importance of the slave population and its labor force whose workers were employed more heavily in agriculture than were free workers; an increase in the share of the slave population under the age of 10; and an increase in the share of the free population made up of women and children whose participation rates were lower than that of adult males. Before 1740 the slave share of the population had been rising and its favorable effect on the participation rate largely offset the influence of the other shifts in the composition of the population. After 1770 all these forces worked in the same direction to lower the overall participation rate.

\section{Sensitivity of the Results}

In order to construct our conjectures we made a number of assumptions, several of which

\footnotetext{
${ }^{45}$ Further work on the import of food from abroad is also called for. Our conjectures have assumed that all imports from abroad were non-food items, although we know that was not the case. The major items, however, were products such as rum, molasses, and tea that were not produced locally, and whose value has been excluded from the base year value of the diet.

46 These high rates of productivity growth stem in part from our assumption that the rural labor force (slaves as well as free) shifted out of agriculture at a relatively rapid rate.
} 
have a noticeable impact on the results. First, we assumed that the value of the colonists' diet remained constant over the entire period. Second, we assumed that nonagricultural output per worker rose faster than the rate of growth in agriculture. ${ }^{47}$ Third, we assumed that the share of the rural population, both free and slave, engaged in agriculture declined over time at the same rate as the share of free population declined in the first half of the nineteenth century. ${ }^{48}$

We believe that the latter two assumptions have biased upward our estimates of economic growth. It is unlikely that the entire rural labor force shifted out of agriculture at the same speed as the free population did in the nineteenth century, and especially unlikely that the slave labor force did so. The decline in the shares over the eighteenth century must have been slower than that which occurred in the nineteenth century for two reasons. First, the rate of productivity growth in agriculture was likely slower in the eighteenth century than in the nineteenth and would have brought about a more gradual shift of the labor force out of agriculture for any given growth in demand. Second, because incomes were higher and growing more rapidly in the nineteenth century, the higher income elasticity of demand for nonfarm products would have induced a more rapid shift in the composition of output away from farming. The evidence we have from probate samples for the colonial period indicates no decline in the relative importance of agricultural occupations between the 1720s and the 1760s (Bentley, 1977). ${ }^{49}$

Our assumptions about the speed of movement out of the agricultural labor force has two

\footnotetext{
47 We used the rate at which it changed over the period 1820 to 1860 , namely at 0.09 percent per year. Although the ratio rose faster over the shorter period between 1820 and 1840, it then declined. We think the longer term average is the more appropriate rate for postulating a trend for earlier years. The rates are from Weiss (1994, Table 1.6).

48 Specifically we have assumed that the fraction of the rural population engaged in agriculture declined at 0.09 percent per year.

49 There was a large number of people listed as having "other" occupations. If they were all farm laborers, then the agricultural share of all occupations rose from 89 percent in 1722-26 to 93 percent in 1757-62. Farmers and Planters alone rose from 44 percent to 53 percent of all occupations, and from 79 to 88 percent of specified occupations (i.e. excluding those listed as "other.")
} 
notable implications. First, this estimate influences the rate at which the nonagricultural labor force increased. If the assumed rate of growth of the nonagricultural labor force is biased upward this gives an upward bias to the estimates of GDP growth because it increases the weight of the sector with the relatively higher average productivity. ${ }^{50}$ Second, a too rapid rate of shift out of agriculture biases upward agricultural productivity and simultaneously biases upward the growth of nonagricultural productivity. ${ }^{51}$

The rates of agricultural productivity growth implied by our baseline conjectures are 0.11 percent per year for the period 1720 to $1770,0.32$ percent per year for the entire period 1720 to 1800, and a whopping 0.45 percent per year in the period 1770 to 1800 . These are fairly high rates of growth of output per worker for U.S. agriculture. Over the entire nineteenth century output per worker in agriculture rose at 0.70 percent per year, but in the first half of the century the rates were much slower than this; 0.14 percent between 1800 and 1820, 0.44 percent between 1820 and 1840, and only 0.24 for the fifty years 1800 to 1850 (Weiss, 1993, Table 2). In light of the fact that the nineteenth century must have witnessed a greater degree of mechanization, economies of scale associated with the westward movement, and improvements in yields resulting from scientific advances in agriculture, it seems unlikely that output per worker could have risen as fast or faster in the colonial period than it did in the first half of the nineteenth. Moreover, the rates of productivity growth implied by our conjectures are noticeably higher than those derived from other independent

\footnotetext{
50 As shown in Table 1, we estimate that nonagricultural productivity was 28 percent higher than agricultural in the Lower South, and as seen in Table 3 the shift effect made a small positive contribution towards increasing GDP per capita.

${ }^{51}$ Modern day intuition may suggest that nonagricultural productivity grows faster than agricultural, but such intuition is not always a good guide as to past performance. The evidence for the nineteenth century indicates that nonagricultural productivity did not always increase faster than agricultural. See Gallman, (1971), Engerman and Gallman (1981) and Weiss (1994).
} 
evidence about the pace of productivity change in agriculture in the Lower South. While there is evidence from contemporary observations of increases in yields per acre and per slave in rice cultivation (see Coclanis 1989, p. 89), there is no suggestion of comparable advances in other agricultural activities. And, the volume of exports per slave -- which should reflect the most dynamic parts of agriculture -- rose at only 0.03 percent per year from 1720 to 1800 , and even during the export boom periods the figure rose at only 0.08 percent per year between 1720 and 1740 and 0.12 between 1740 and 1770. (Mancall, Rosenbloom and Weiss 2000). Thus we think our conjectures of economic growth are biased upward by our assumptions relating to agricultural productivity.

Estimates of the value of food consumed and produced are the crux of the matter, and so our assumptions about those items are critical. We have assumed that the value of the colonists' diet did not change over the century. We believe this was likely the case. Further, we made the argument in order to gauge the impact of a large but slow-growing food producing sector on the region's economy. Food production was the dominant activity of the colonists and was at least as important an influence on the economy's performance as the more dynamic export sector. When the weight of this slow-growing sector is taken into account, the economy's performance is not as buoyant as we have been led to believe by focusing on exports alone, or when focusing on only the low country rather than the entire region.

If colonists' diets had improved over time and the food producing part of the agricultural sector had grown more rapidly to provide it, the economy would have grown faster overall. Consider for example the consequences of an adult's and a child's diet in 1730 having been equal to that implied by the Rules for Georgia for 1735 (\$28 for an adult and \$14 for a child) and having increased at a constant rate from those values to the base year figures for 1800 and grown at that 
same rate in the decade before 1730 . The value of each of their diets would have risen at 0.55 percent per year; the weighted average for the colonists would have increased between 1720 and 1800 at 0.51 percent per year; and when combined with the figures for slaves the diet for the entire population would have risen at 0.45 percent per year. ${ }^{52}$ These are healthy advances in the value of the diet considering that they are not reflective of any increase in the costs of distribution. The upshot for the economy as a whole is very favorable. GDP per capita (narrowly defined) would have risen between 1720 and 1770 at 0.38 percent per year, four times as fast as the 0.09 percent in the baseline conjecture, and by 0.34 percent per year for the longer period 1720 to 1800 , nearly four times as fast as growth shown in the baseline case. These are more positive results and put the rates of growth of GDP per capita into the 0.3 to 0.5 range of rates put forth by McCusker and Menard for all the colonies, but we think they are implausibly high.

This alternative scenario about food consumption and production yields important implications about productivity as well, and those implications suggest these rates of growth are too high to be plausible. If consumption had risen at these higher rates, then the rate of growth of agricultural output per worker would have been 0.43 percent per year between 1720 and 1770 and a very robust rate of 0.60 per cent per year from 1720 to 1800 . These rates of advance would be two to two and one-half times as fast as that which prevailed in American agriculture in the first half of the nineteenth century. ${ }^{53}$ Consequently if the alternative trend in the colonists' diet had occurred it

\footnotetext{
52 The weighted average rises more slowly because children were an increasing share of the colonist population. We have not made an allowance for differences between the diet of an adult male and adult female. Had we done so, the weighted average would have grown slightly slower still because the female diet was slightly less valuable and the female share of the population had increased over time.

53 This is the rate when GDP excludes home manufacturing and farm improvements. Weiss (1993, Tables 1 and 2). This alternative trend in the colonist's diet also implies that its value in 1720 would had to have been about equal to that of a slave in that year, and less than we estimate the value of the slave's diet to be in 1800 .
} 
had to have rested on very implausible rates of growth of agricultural productivity.

\section{The Indian Experiment}

We have also produced estimates of GDP and its components for the Native American Indian population as well as estimates for the combined population. These are reported in Table 4. This effort is more of a hypothetical experiment than the conjectural estimates for the colonists and their slaves because there are so few statistics about the economic activity of Native Americans. To carry out the exercise we have had to resort to making a number of assumptions about how much Native Americans consumed, how productive they were, and how their labor was divided between agricultural and nonagricultural work. Nevertheless, the quantitative importance of the Native American population, especially at the beginning of the period when they accounted for somewhere between 30 and 55 percent of the region's population, and the fact that many Indians regularly engaged in commercial relations with colonists justifies the experiment. ${ }^{54}$

We have made the following assumptions about the Native Americans. First, their consumption of food was equal to 75 percent that of a free colonist at each benchmark date. ${ }^{55}$ Second, their consumption of shelter was equal to that of slaves in 1800 and remained constant over time. ${ }^{56}$ Third, deerskins were the only agricultural export Indians produced and that they received 40

\footnotetext{
54 Recent work by Baron, Hood, and Izard (1996) indicates more frequent and greater integration than previously believed. The interaction of course varied over time and across regions. For more discussion of these issues, see Mancall, Rosenbloom and Weiss (1999b).

${ }^{55}$ Evidence from Oglethorpe's expedition against St. Augustine indicates that the value of an Indian diet may have been as low as 30 percent that of a male colonist (CRSC, vol. II, pp.175-201). We think this is too low, perhaps because Indians on expeditions were expected to have foraged for much of their food. We have instead put the relative value at 75 percent in all years, assuming thereby that the Indians' diet was no less valuable than that of slaves.

${ }^{56}$ It is possible, perhaps likely, that Indian housing was more valuable than that of slaves, but there is little evidence to suggest that it improved over the eighteenth century. See Williams (1989) and Waselkov and
} 
percent of the value of those exports. ${ }^{57}$ Fourth, the labor force participation rate and the agricultural share of the labor force were the same for males and females, were equal to the 1800 rates for slaves, and remained constant over time. ${ }^{58}$ Fifth, the ratio of nonagricultural to agricultural productivity in the base year of 1800 was the same as that for the colonists and slaves. ${ }^{59}$ Sixth, nonagricultural productivity changed at the same rate as that for agriculture. ${ }^{60}$

The combination of these assumptions yields an output per capita for Native Americans that did not change much over time, since the only source of temporal change is fluctuations in deerskin exports. Indian GDP per capita was around \$35 in each year. This was equal to 64 percent that of the non-Indian population in 1720 but fell to around 59 percent at the end of the century. The more noteworthy effect of including Native Americans shows up in our multicultural estimate of the value of output per capita for the combined populations. That figure increased noticeably over the course of the period from $\$ 49$ in 1720 to $\$ 59$ in 1800 using the smaller Indian population figure, and from

Braund (1995).

57 See Brown (1975, p. 123) and Murphy (1998, 153-55). The proportion of the final price of deerskin exports that the Indians may have received appears to have been around 40 percent in the early 1700 s. It may have risen to a peak near the middle of the century, and then fallen back. For our initial conjectures we have assumed the 40 percent figure was the long term trend value.

58 The average labor force participation rate for all male and female Native Americans and the industrial composition of that employment is unlikely to ever be known with great accuracy because there was variation across tribes in the extent to which men and women engaged in the different tasks and because there are no statistical compilations of their economic activities. There is little question that agriculture engaged most of the workers, especially when agriculture is defined to include hunting and fishing as is the case in our conjectures. In most tribes there was a clear sexual division of labor: women were the predominant workers in crop agriculture, while men helped with the clearing of land and were engaged primarily in hunting and fishing. We have assumed that the agricultural share of the labor force was 86 percent, the same share as that for slaves in 1800. See for example Brown (1995), Bonvillain (1989, 1-28); Cronon (1983, pp. 40, 44-48); and Mancall, Rosenbloom and Weiss (1999a).

59 That ratio was 1.28. The level of agricultural productivity for Indians was calculated by dividing the estimate of agricultural output by the estimated labor force. This resulted in output per worker for Native Americans that was equal to about 35 percent that of the colonists and slaves.

${ }^{60}$ This differs from the assumption made in our baseline case for the colonists and slaves for whom we postulated faster growth in nonagricultural productivity based on evidence from the nineteenth century. 
$\$ 45$ to $\$ 58$ using the more comprehensive measure of the Indian population. These results are, of course, a manifestation of the role of food consumption in the estimation. Native Americans were a much larger portion of the population in 1720 than in 1800 , and their consumption standard was a fraction of the non-Indian population. Their inclusion pulls down the weighted average consumption per capita in 1720 but has little effect on the 1800 figure, making for an increase in food consumption for the entire population of $\$ 2.50$. This increase in food production in turn contributed to the positive rate of productivity advance in agriculture.

\section{Conclusions}

Our conjectures about growth of output per capita in the Lower South indicate that the region advanced somewhat over the course of the eighteenth century, perhaps around 0.09 percent per year. This is a more favorable result than Mancall and Weiss (1999) found for the colonies as a whole, but still does not measure up to the rates of advance McCusker and Menard (1985) have postulated for the colonies as a whole. If the Lower South's economy were the most export-oriented and one of the most successful in British America, then the likelihood of growth of GDP per person for the entire British mainland colonies being as high as 0.5 percent per year, or even above 0.3 percent per year, seems remote.

At the same time, this conjectural exercise provides some support for the traditional and widely held view that export success led to economic growth more generally. This was in part the case for the Lower South in the period 1740 to 1770 when the growth of exports combined with other favorable developments to propel GDP per capita for the region upward at an annual rate of around 0.4 percent per year. As good a performance as exports exhibited, this period also serves to 
demonstrate the impact of the domestically-oriented part of agriculture on the entire economy. In those years, the production for the domestic sector was the more positive force.

The weight of the domestic sector is even more evident in the period 1720-40. Even with export growth surging upward at over 6 percent per year, the food producing sector held the entire economy back. Had export growth continued at that high rate, the economy might have fared better in other years when the domestic sector was not such a drag. Export growth did not continue at that high rate, however. Instead of continually pushing up output per capita to ever greater heights, exports appear to have contributed some degree of volatility to the region's economy. These results make clear how important it is to take into account all the parts of the economy. The emphasis in previous research on South Carolina, and in particular the low country's export and economic success, has fostered a misleading view of the performance of the entire region. The low country was only a portion of the region, and in demographic terms a dwindling one at that. The economic activity taking place in the more populous North Carolina and in the rapidly growing back country of South Carolina played a large role in shaping the region's economic performance.

Our conjectures have focused on the per capita value of GDP because of its relationship to the standard of living. Only if the per capita value rises can we know that the expansion of the economy has made its members better off on average. But our focus on the per capita figures may downplay the region's success. The region's aggregate economy and population were growing rapidly in the eighteenth century. Colonists had more children because they felt they could afford to and because the children would eventually become very productive workers; others migrated there because the economy looked attractive to them. These responses are signs of a successful economy. Indeed, the fact that the region's economy could forge ahead in the wake of such population 
increases attests to its capabilities.

Part of the reason why the per capita figure rose so slowly, or not at all, is because the population was growing rapidly and in ways that held growth in check. Throughout the entire period the share of the population under the age of 10 was increasing and after 1770 the free share of the population was increasing and that of slaves was decreasing. These shifts served to hold down and indeed decrease the labor force participation rate; the number of dependents was rapidly increasing. The population was growing by adding numbers of people who were not as productive as full time workers. As a consequence even though workers were becoming more productive, the impact of the improvement in productivity was muted because of the decline in labor inputs per capita due to the demographic shifts.

The region's economy included others besides colonists and slaves. Though these newcomers became a majority of the population, at the beginning of the colonial period they were but a minority. The economy created by the colonists and slaves had innumerable connections to the economy of Native American Indians and not only in the deerskin trade; as we have argued elsewhere, Indians' participation in clearing land, preserving peace, and provisioning traders, among other activities, renders incomplete any measure of the regions' economy that does not take into account Indians' varied economic activities (Mancall, Rosenbloom, and Weiss, 1999b). If the impact of the Native Americans is taken into account, the performance of the colony looks a bit better. This of course reflects the assumptions underlying our conjectures about the Indians' economic performance, and the actual picture could have been much different. Still, however different the economic performance of the Indians might have been, their numbers were initially so large and the demographic shift was so pronounced that the colony's economy had to have been affected. Our 
conjectures highlight the dimensions of this contribution.

The favorable impact of this momentous demographic shift, however, highlights the shortcomings of relying on a measure of tangible output such as GDP to gauge the progress of a society. Progress in this case was purchased at the expense of a large segment of the society. The measured increases in GDP per capita were obtained in effect by removing some of the capitas, not by making everyone better off in some average sense. This is clearly not what Kuznets and others had in mind when they developed national income statistics. These estimates of GDP per capita for the multiethnic population -- that which includes the Native Americans -- are not a good measure of improvement for that society. Rather they serve to highlight the ways and extent to which the colonists may have benefitted from being part of this society, and from becoming the dominant portion of it. 


\section{Bibliography}

Baron, Donna, Edward J. Hood and Holly V. Izard. 1996. "They Were Here All Along: The Native American Presence in Lower-Central New England in the Eighteenth and Nineteenth Centuries," William and Mary Quarterly $3^{\text {rd }}$ Ser., 53, pp. 561-86.

Bentley, William George. 1977. "Wealth Distribution in Colonial South Carolina," Ph.D diss. Georgia State University.

Bonvillain, Nancy. 1989 'Gender Relations in Native North America,' American Indian Culture and Research Journal 19.

Brown, Kathleen. 1995. "The Anglo-Algonquian Gender Frontier," in Nancy Shoemaker, ed., Negotiators of Change: Historical Perspectives on Native American Women. New York: Routledge.

Brown, Philip M. 1975. "Early Indian Trade in the Development of South Carolina," South Carolina Historical Magazine 76, no. 3, pp. 118-128.

Butlin, N.G. 1986. "Contours of the Australian Economy," Australian Economic History Review XXVI, no.2, 96-147.

Candler, Allen D. 1904-1916 The Colonial Records of the State of Georgia, compilations of transcripts of records in the Public Record Office begun by Allen D. Candler and completed by William J. Northen and Lucian Lamar Knight.

Chaplin, Joyce E. 1993. An Anxious Pursuit: Agricultural Innovation and Modernity in the Lower South, 1730-1815. Chapel Hill and London: University of North Carolina Press.

Clifton, James M. 1981. "The Rice Industry in Colonial America," Agricultural History 55 (1981) 266-83

Coclanis, Peter. 1989. The Shadow of a Dream, New York and Oxford: Oxford University Press.

Cronon, William. 1983. Changes In the Land: Indians, Colonists, and the Ecology of New England. New York: Hill and Wang.

Crouse, Maurice A. 1977. The Public Treasury of Colonial South Carolina. Columbia, SC: University of South Carolina Press for the South Carolina Tricentennial Commission.

CRSC. Colonial Records of South Carolina. Journals of the Commons House of Assembly. 14 vols. J. H. Easterby et al. Columbia: South Carolina Department of Archives and History, 1951-89.

David, Paul. 1967 "The Growth of Real Product in the United States Before 1840: New Evidence, Controlled Conjectures," Journal of Economic History, 27, no. 2, pp. 151-197.

Dethloff, Henry C. 1982. “The Colonial Rice Trade." Agricultural History 56, no. 1 (Jan.), 231-43.

Easterlin, Richard A. 1960. "Interregional Differences in per Capita Income, Population and Total Economy." In Trends in the American Economy, William Parker, ed. Studies in Income and Wealth, vol. 24. Princeton: Princeton University Press.

Egnal, Marc. 1975. "The Economic Development of the Thirteen Continental Colonies, 1720 to 1775," William and Mary Quarterly, 3d Ser., XXXII, pp. 191-222.

Egnal, Marc. 1998. New World Economies. New York: Oxford University Press,

Engerman, Stanley and Gallman, Robert. 1981. "Economic Growth 1783 to 1860," Research in Economic History, 8, pp. 1-46.

Fishlow, Albert. 1964. “Antebellum Interregional Trade Reconsidered.” American Economic Review 54, pp. 352-64.

Fouts, Raymond Parker. 1999. Vestry Minutes of St. Paul's Parish Chowan County, North Carolina, 17011776, 2nd ed. Cocoa, FL: GenRec Books

Gallman, Robert. 1966. "Gross National Product in the United States, 1834-1909.” In Output, Employment and Productivity in the United States after 1800. Dorothy Brady, ed. Studies in Income and Wealth, vol 30. New York: National Bureau of Economic Research.

Gallman, Robert. 1971. "The Statistical Approach: Fundamental Concepts Applied to History," in G.R.Taylor 
and L.F.Ellsworth, eds. Approaches to American Economic History. Charlottesville: The University Press of Virginia.

Gallman, Robert. 1992. "American Economic Growth Before the Civil War," in R. Gallman and J. Wallis, American Economic Growth and Standards of Living Before the Civil War. Chicago: University of Chicago Press.

Gray, Lewis C. 1958. History of Agriculture in the southern United States to 1860. Gloucester, MA, Peter Smith. 1958.

Gray, Ralph and Wood, Betty 1976. "The Transition from Indentured to Involuntary Servitude in Colonial Georgia," Explorations in Economic History 13, pp. 353-370.

Hughes, Kaylene. 1985. "Populating the Back Country: The Demographic and Social Characteristics of the Colonial South Carolina Frontier, 1730-1760.” Ph. D. Diss., Florida State University

Johnson, George Lloyd, Jr. 1997. The Frontier in the Colonial South: South Carolina Backcountry, 17361800. Contributions in American History, no. 175. Westport, CT and London: Greenwood Press.

Jones, Alice Hanson. 1980. Wealth of a Nation to Be. New York: Columbia University Press.

Kahn, Charles. 1992. "A Linear Programming Solution to the Slave Diet," in Without Consent or Contract: Technical papers, Vol. III. Robert Fogel and Stanley Engerman, eds. New York: W.W. Norton, (1992) 522-535.

Klepp, Susan. 1994. "Seasoning and Society: Racial Differences in Mortality in Eighteenth-Century Philadelphia," William and Mary Quarterly 3rd Ser., LI, pp. 481-82.

Klein, Rachel N. 1990. Unification of a Slave State: The Rise of the Planter Class in the South Carolina Backcountry, 1760-1808. Chapel Hill and London: University of North Carolina Press.

Klingberg, Frank J. 1941. An Appraisal of the Negro in Colonial South Carolina. Washington, DC: The Associated Publishers

Kuznets, Simon. 1946. National Product Since 1869. New York: National Bureau of Economic Research.

Kuznets, Simon. 1952. "Long Term Changes in the National Income of the United States of America since 1870," in Income and Wealth of the United States, Trends and Structure. International Association for Research in Income and Wealth, Income and Wealth Series II, Baltimore: The Johns Hopkins University Press.

Lebergott, Stanley. 1966. "Labor Force and Employment, 1800-1960” In Output, Employment and Productivity in the United States after 1800. Dorothy Brady, ed. Studies in Income and Wealth, vol 30. New York: National Bureau of Economic Research.

Mancall, Peter C. and Weiss, Thomas. 1999. "Was Economic Growth Likely in Colonial British North America," Journal of Economic History, 59 (1999) 17-40.

Mancall, Peter C., Joshua L. Rosenbloom and Thomas Weiss. 1999a. "Economic Activity of Native Americans. Paper presented at the meetings of the Economic History Association, October 1999, Baltimore, MD. Photocopy, University of Kansas.

Mancall, Peter C., Joshua L. Rosenbloom, and Thomas Weiss. 1999b. "Indians and the Economy of Eighteenth-Century Carolina." Paper presented at the Emergence of the Atlantic Economy Conference, Charleston, October 1999. Forthcoming in Peter Coclanis, ed., The Emergence of the Atlantic Economy (Charleston: University of South Carolina Press).

Mancall, Peter C, Rosenbloom, Joshua and Weiss, Thomas. 2000 "Slave Prices and the Economy of South Carolina, 1722-1809.” NBER Historical Working Paper, no. 120.

McCusker, John, and Menard, Russell. 1985. The Economy of British America,1607-1789. Chapel Hill: University of North Carolina Press.

McCusker, John J. 1992. How Much is That in Real Money? A Historical Price Index or Use as a Deflator of Money Values in the Economy of the United States. Worcester, MA: American Antiquarian Society. 
Menard, Russell R. 1995. "Slave Demography in the Lowcoutnry, 1670-1740: From Frontier to Plantation Region," South Carolina Historical Magazine, 96, no.4

Menard, Russell R. 1996. "Economic and Social Development of the South." In The Cambridge Economic History of the United States, vol. 1: "The Colonial Era. Stanley L. Engerman and Robert E. Gallman, eds. Cambridge: Cambridge University Press.

Metzer, Jacob. 1995. "Two Peoples in One Country: A comparative Look at the Economic Record and SocioEconomic Profile of Mandatory Palestine," (mimeo) Paper presented at the International Economic Association Eleventh World Congress, Tunis, December.

Morgan, Philip D. 1983. "Black Society in the Lowcountry, 1760-1810." In Slavery and Freedom in the Age of the American Revolution. Ira Berlin and Ronald Hoffman, eds. Charlottesville: University of Virginia Press.

Morgan, Philip D. 1998. Slave Counterpoint: Black Culture in the Eighteenth-Century Chesapeake and Lowcountry. Chapel Hill and London: University of North Carolina Press for the Omohundro Institute of Early American History and Culture.

Murphy, Edward. 1998. "The Eighteenth Century Southeastern American Indian Economy: Subsistence vs. Trade and Growth." In The Other Side of the Frontier: Economic Explorations into Native American History. Linda Barrington, ed. Boulder: Westview Press.

Nash, R. C. 1992. "South Carolina and the Atlantic Economy in the Late Seventeenth and Eighteenth Centuries." Economic History Review 45, no. 4, pp. 677-701.

North, Douglass. 1961. The Economic Growth of the United States, 1790-1860. New York: Prentice Hall.

Pitkin, Timothy. 1967. A Statistical View of the Commerce of the United States. 1816; reprinted Augustus Kelley.

Richardson, David. 1991. "The British Slave Trade to Colonial South Carolina." Slavery and Abolition 12, no. 3 , pp. $125-72$.

Salley, Jr., A.S., ed. 1919. Minutes of the Vestry of St. Helena's Parish, South Carolina, 1726-1812. Columbia: Historical Commission of South Carolina.

Shepherd, James and Walton, Gary. 1972. _Shipping, Maritime Trade and the Economic Development of Colonial North America. Cambridge: Cambridge University Press.

Shepherd, James and Williamson, Samuel. 1972. "The Coastal Trade of the British North American Colonies, 1768-1772," Journal of Economic History, 32, no. 4, pp. 783-810.

Soltow, Lee. 1989. Distribution of Wealth and Income in the United States in 1798. Pittsburgh University Press.

Soltow, Lee and Land, Aubrey. 1980. "Housing and Social Standing in Georgia, 1798," The Georgia Historical Quarterly LXIV, pp. 448-458.

Taylor, George R. 1964. “American Economic Growth Before 1840: An Exploratory Essay,” Journal of Economic History, 24, 427-44.

Towne, Marvin and Rasmussen, Wayne. 1960. "Farm Gross Product and Gross Investment in the Nineteenth Century," In Trends in the American Economy, William Parker, ed. Studies in Income and Wealth, vol. 24. Princeton: Princeton University Press.

Tryon, Rolla. 1966. Household Manufactures in the United States New York: Johnson Reprint Corporation, 1966.

U.S. Bureau of the Census. 1975. Historical Statistics of the United States. Washington D.C.: GPO, 1975.

U.S. Department of Agriculture. 1942. "Fuel wood Used in the United States, 1630-1930." Circular \#641. Washington, DC. GPO.

Waselkov, Gregory A. and Braund, Kathryn E. 1995. William Bartram on the Southeastern Indians. Lincoln: University of Nebraska Press.

Weiss, Thomas. 1992. "U.S. Labor Force Estimates and Economic Growth, 1800 to 1860," in R. Gallman 
and J. Wallis, eds., American Economic Growth and Standards of Living Before the Civil War. Chicago: University of Chicago Press.

Weiss, Thomas. 1993. "Long Term Changes in U.S. Agricultural Output per Worker, 1800-1900.” Economic History Review 46, no. 2, pp. 324-41.

Weiss, Thomas. 1994. "Economic Growth Before 1860: Revised Conjectures," in Thomas Weiss and Donald Schaefer, eds. American Economic Development in Historical Perspective. Stanford: Stanford University Press.

Williams, Michael. 1989. Americans and Their Forests: A Historical Geography. Cambridge, England: Cambridge University Press.

Wood, Peter H. 1974. Black Majority: Negroes in Colonial South Carolina from 1670 through the Stono Rebellion. New York: Knopf

Wood, Peter H. 1989. "The Changing Population of the Colonial South: An Overview by Race and Region, 1685-1790.” In Powhatan's Mantle. Peter H. Wood, Gregory A. Waselkov, Thomas M. Hatley, eds. Lincoln: University of Nebraska Press. 
Table 1

Estimates of GDP and Components in the Base Year of 1800:

U.S. and Lower South

(U.S. dollars, prices of 1840)

United States

Non-Indian
Population

\section{Lower South}

Non-Indian
Population

Totals Per Capita

(\$000s)

$\$ 64,362$

(\$s)

\author{
Ratio of per \\ capita values \\ Lower South \\ to US \\ 0.89
}

1.03

$\begin{array}{lllll}158,653 & 29.90 & 33,615 & 30.80 & 1.03\end{array}$

less intra-colonial food imports

Food Production

158,653

29.90

1,146

1.05

NA

32,469

29.75

0.99

35,258

6.64

6,662

6.10

0.92

17,806

3.36

5,435

4.98

1.48

1,637

1.50

NA

Non-Agricultural Output

Shelter

29,188

5.50

3,758

3.44

0.63

110,591

20.84

14,400

13.19

0.63

1,713

428

0.24

1,262

344

0.26

451

84

0.20

NonAgricultural

Output per worker

Agricultural

NonAgricultural

168

134

0.80

245

172

0.70

1.46

1.28

0.88

Ratio NonAgr. To Agr. (k)

Notes: The 1800 population figures for the U.S. and the Lower South are for the White and Negro population estimated to be in residence on July 1. (U.S. Bureau of the Census, 1975, series A-7). The population of the Lower South includes that in Georgia, North Carolina, South Carolina and Tennessee. The figures for GDP and its components for the U.S. in 1800 were taken from Mancall and Weiss (1999).

The 1800 per capita GDP figure for the Lower South was set at 91 percent of the national figure when GDP is defined broadly to include home manufacturing and farm improvements. The narrowly defined GDP per capita was obtained by deducting estimates of those two items, and that reduced the Lower South's relative position slightly to 89percent. Easterlin (1960) estimated that per capita income for the Lower South in 1840 was equal to between 83 
and 91 percent of the per capita figure for the nation. We used the higher of these ratios in order to maximize the possibility of economic growth in the century leading up to 1800 . The other figures for the Lower South were obtained as follows.

The per capita food figures for each of the population groups (free adults, free children, and slaves) in the Lower South in 1800 was assumed to equal the national average estimates derived in Mancall and Weiss (1999). The value of food produced for domestic consumption in 1840 was derived by subtracting from the value of agricultural products those items that were not food (e.g. firewood, cotton, tobacco, etc.) and the value of crude and manufactured food exports. (See Gallman 1960, table, A-2; and U.S. Census Bureau 1975, series U-215 and 216). Because we wanted a figure to represent farm production, we valued the food at farm prices and thereby excluded the value of distribution included in the prices that the consumers would have ultimately paid. Because the per capita value of GDP in 1800 is the same regardless of which value of food consumption we use, any difference in the latter figures is shifted into the residual item "nonagricultural output."

The base year value of firewood per person for the Lower South was calculated from the USDA estimates of firewood. (U.S. Department of Agriculture 1942, Table 2). We used the information reported for the South Atlantic (NC, SC and VA) to calculate a per capita figure for the Lower South. The calculation was based on the reported figures on the firewood consumed for the periods 1790-99 and 1800-1809. We further assumed that slaves consumed one-half the quantity consumed by free persons.

The estimate of food imports from other states in 1800 was assumed to equal the 1770 value of food imports from other colonies. The figure was calculated from evidence compiled by Shepherd and Williamson $(1972$, table 2) for $1768-1772$.

We produced estimates of domestically produced exports for two base years 1800 and 1770. It was necessary to produce the two figures because of the enormous disruption of trade that occurred during the Revolutionary War years. The 1800 value of domestically produced exports was derived from the statistics presented by Pitkin (1967). We derived the regional figure as the sum of estimates for each of three states, adjusting each series for the value of reexports included in the reported totals. These figures were converted to a constant price series by deflating them by the export price index constructed by North (1961, pp. 221 and 239). We further assumed that all the domesticallyproduced exports from the Lower South were agricultural products.

The estimate for 1770, which is the figure that we extrapolate to earlier years, was calculated from the evidence assembled by Shepherd and Walton (1972). They presented exports of commodities from the Lower South to all destinations in each year 1768-1772 (1972, p. 94-95). Those exports were valued in Pounds Sterling at current prices. We converted them to dollars at the exchange rate of $\$ 4.44$ and then deflated them by the David-SolarMcCusker index (McCusker 1992) in order to obtain values in prices of 1840. The figures may include some small amount of re-exports, but we have assumed that they were all produced domestically, and we further assumed that they were all agricultural products. When converted and divided by the population we obtained an average per capita figure for 1770 of $\$ 7.13$ (see Table 2).

For agricultural exports to other states we used the evidence on interregional shipments in the period 1840 to 1860 compiled by Fishlow (1964) to put the 1800 figure at $\$ 1.50$. Shepherd and Williamson (1972) provide a figure of $\$ 1.45$ for 1770 . The latter was used for extrapolation to earlier years.

The value of shelter services is based on the value of the stock of dwellings in 1798 and the ratio of the annual flow of shelter to that stock taken from the work of Gallman. The 1798 figures on the stock of dwellings came from the statistics collected by the Secretary of the Treasury as part of the Direct Tax assessed in that year. We used the figures as reported by Timothy Pitkin (1967) and adjusted them for omitted values according to the procedures developed by Lee Soltow (1989) and Soltow and Land (1980). The annual flow of shelter from that stock was revalued in the prices of 1840 by using the price deflator for the gross rental value of farm dwellings estimated by Towne and Rasmussen (1960). We assumed that these figures pertained to the free population. We set the value of slave 
dwellings equal to the value of those dwellings of free persons located in rural areas and valued at less than $\$ 100$. The value of all such dwellings amounted to only $\$ 2.77$ per free person, and using the same service flow per year of 22 percent we obtain the annual value of shelter of $\$ 0.60$. If the U.S. figure for shelter were calculated in this same way the value would be $\$ 9.50$ for the non-Indian population.

The residual nonagricultural output is the difference between the estimated total GDP and the estimates of all the other components. This residual encompasses all nonagricultural output, except shelter. In other words it includes the output of manufacturing, mining, construction, and final services flowing to consumers other than shelter. Thus it includes the value of government services as well as investment.

The labor force figures are from Weiss (1992), modified as follows. Weiss's earlier estimates assumed that the share of the slave population aged 10 and over in 1800 (and 1810) was equal to that for 1820, namely 65 percent. The evidence we have compiled in the current research indicates that the 65 percent figure is too low. We derived an alternative value ( 68 percent) by interpolating between the shares found for the colonial period and the 1820 figure.

The value of $\mathrm{k}$, the ratio of nonagricultural productivity to agricultural, for the Lower South may appear low, but the evidence for later years suggest instead that it may be too high.. In 1850 and 1860, when we can make such comparisons, the southern ratio equaled only 60 percent that for the nation. Had that same relative position held in 1800 , then the value of $\mathrm{k}$ for the Lower South would be only 0.84 . 
Table 2

Per Capita Values of Agricultural Output for Colonists and Slaves in the Lower South, 1720 to 1800

\begin{tabular}{|c|c|c|c|c|c|c|c|c|}
\hline \multirow[b]{2}{*}{ Year } & \multicolumn{3}{|c|}{ Food Production } & \multicolumn{5}{|c|}{ Agricultural Exports } \\
\hline & $\begin{array}{c}\text { Food } \\
\text { Consumed }\end{array}$ & $\begin{array}{l}\text { less Food } \\
\text { Imported }\end{array}$ & $\begin{array}{c}\text { Food } \\
\text { Produced }\end{array}$ & Firewood & Abroad & $\begin{array}{l}\text { to Other } \\
\text { Colonies }\end{array}$ & Total & $\begin{array}{c}\text { Agricultural } \\
\text { Output }\end{array}$ \\
\hline 1720 & 29.22 & 0.76 & 28.47 & 4.12 & 6.50 & 1.96 & 8.46 & 41.04 \\
\hline 1740 & 28.40 & 2.80 & 25.59 & 4.11 & 7.82 & 1.55 & 9.37 & 39.07 \\
\hline 1770 & 29.01 & 1.04 & 27.97 & 5.74 & 8.21 & 1.41 & 9.62 & 43.34 \\
\hline 1800 & 30.80 & 1.05 & 29.75 & 6.10 & 4.98 & 1.50 & 6.48 & 42.34 \\
\hline \multicolumn{9}{|c|}{ Average Annual Rates of Change } \\
\hline $720-1770$ & -0.01 & 0.64 & -0.04 & 0.67 & 0.47 & -0.66 & 0.26 & 0.11 \\
\hline $720-1800$ & 0.07 & 0.41 & 0.06 & 0.49 & -0.33 & -0.33 & -0.33 & 0.04 \\
\hline $720-1740$ & -0.14 & 6.78 & -0.53 & -0.01 & 0.93 & -1.16 & 0.51 & -0.25 \\
\hline $740-1770$ & 0.07 & -3.26 & 0.30 & 1.12 & 0.17 & -0.32 & 0.09 & 0.35 \\
\hline $770-1800$ & 0.200 & 0.03 & 0.21 & 0.20 & -1.65 & 0.21 & -1.31 & -0.08 \\
\hline
\end{tabular}


Table 2 Continued

Notes: The value of food consumed per capita (c) is a weighted average of the value consumed by the colonists $\left(\mathrm{c}_{\mathrm{c}}\right)$ and that consumed by the slaves $\left(\mathrm{c}_{\mathrm{s}}\right)$, and the average for the colonists is a weighted average of that consumed by an adult $\left(\mathrm{c}_{\mathrm{a}}\right)$ and that consumed by a child $\left(\mathrm{c}_{\mathrm{k}}\right)$, where the weights are their respective shares of the population. Children are those under the age of 10 . We assumed that the per capita consumption figure for free colonists was constant over time and equal to the value we estimated for 1800 . The rationale for this assumption is described in the text.

The per capita figure for slaves was assumed to equal 75 percent that of a colonist in 1800, which amounted to 6.9 cents per day. We assumed that the daily cost a century earlier was equal to the least-cost diet estimated by Kahn (1992). His estimate in 1860 prices equaled 75 percent of the cost estimated by Fogel and Engerman or Sutch. Because our 1800 figure is comparable to the estimates by Fogel and Engerman or Sutch, we set the 1700 figure at 75 percent of our 1800 figure. We then assumed that the value of slave consumption increased at a constant rate between 1700 and 1800 .

The estimate of food imports from and agricultural exports to other colonies for 1770 comes from Shepherd and Williamson (1992, Table 2). We used statistics on tonnage entering and clearing Charleston (Clowse, 1981, Table C-11) to estimate the value of food imported from and the value of agricultural exports to other colonies at eight dates between 1717 and 1768-72. We assumed that the value of intra-colonial shipments of food fluctuated in proportion to the changes in tonnage entering and clearing the port of Charleston and changes in the value of foreign trade per ton entered or cleared. In order to obtain the value for the specific benchmark dates shown in this table we interpolated between the nearest years for which we had estimates. 
Table 3

Conjectural Estimation of GDP per capita, 1720-1800

\begin{tabular}{|c|c|c|c|c|c|}
\hline \multirow[t]{2}{*}{ Year } & $\begin{array}{l}\text { Ratio of Labor Force } \\
\text { to Population }\end{array}$ & $\begin{array}{l}\text { Output per } \\
\text { Worker }\end{array}$ & $\begin{array}{c}\text { Intersectoral Shift } \\
\text { Effect }\end{array}$ & $\begin{array}{c}\text { Extrapolated } \\
\text { Value of GDP } \\
\text { per Capita }\end{array}$ & $\begin{array}{l}\text { GDP per } \\
\text { Capita }\end{array}$ \\
\hline & Estimated Values & & & & \\
\hline 1720 & 0.487 & $\$ 104$ & 1.04 & $\$ 52.66$ & $\$ 54.96$ \\
\hline 1740 & 0.491 & 97 & 1.04 & 49.27 & 51.65 \\
\hline 1770 & 0.477 & 110 & 1.04 & 55.05 & 57.61 \\
\hline \multirow[t]{2}{*}{1800} & 0.392 & 134 & 1.06 & 55.54 & 58.98 \\
\hline & Index Values & $(1720=100)$ & & & \\
\hline 1720 & 1.00 & 1.00 & 1.00 & 1.00 & 1.00 \\
\hline 1740 & 1.01 & 0.92 & 1.00 & 0.94 & 0.94 \\
\hline 1770 & 0.98 & 1.05 & 1.01 & 1.04 & 1.05 \\
\hline 1800 & 0.81 & 1.28 & 1.02 & 1.05 & 1.07 \\
\hline \multicolumn{6}{|c|}{ Average Annual Rates of Change } \\
\hline $1720-1770$ & -0.04 & 0.11 & 0.01 & 0.09 & 0.09 \\
\hline $1720-1800$ & -0.27 & 0.32 & 0.02 & 0.07 & 0.09 \\
\hline $1720-1740$ & 0.05 & -0.38 & 0.00 & -0.33 & -0.31 \\
\hline $1740-1770$ & -0.10 & 0.45 & 0.02 & 0.37 & 0.37 \\
\hline $1770-1800$ & -0.66 & 0.65 & 0.04 & 0.03 & 0.08 \\
\hline
\end{tabular}

Notes: The labor force was estimated as the product of the population aged 10 and over times the labor force participation rates, with separate estimates being made for slaves and free persons. The participation rates are those for 1800 (Weiss, 1992). The agricultural labor force used to calculate agricultural output per worker and the shift effect is the sum of the rural agricultural labor force and the urban. There were very few such workers in cities, but this method allows for urbanization to influence the growth of the agricultural labor force. The rural labor force was estimated as the product of rural agricultural participation rates time the population age 10 and over. The participation rates were assumed to change over time at the same rate as they did in the period 1800 to 1860 (See Weiss, 1992). Agricultural output used to calculate the output per worker figure is from Table 2. The intersectoral shift effect measures the impact of changes in the distribution of the labor force between agriculture and nonagriculture and equals $\mathrm{S}_{\mathrm{a}}+\left(1-\mathrm{S}_{\mathrm{a}}\right) \mathrm{k}$

The three input values (cols. 1-3)are multiplied to produce the extrapolated value of GDP per capita. The independent estimate of the value of shelter is then added to the extrapolated value to obtain the full measure of GDP, narrowly defined (i.e. excluding home manufactures and farm improvements)

Per capita values of shelter in 1800 of $\$ 4.80$ for free persons and $\$ 0.60$ for slaves were derived from the value of dwellings reported in the tax inventories of 1798 (Soltow, 1989, table 10) and an assumed annual flow of shelter services from that stock (Gallman, 1966). Because those figures were calculated as the product of the stock of dwellings and an annual flow of housing service emanating from that stock, we used an index of change in the stock of dwellings to extrapolate the 1800 figure backward to 1700 . We based the index on Jones's $(1980$, p.78) estimate of the rate of growth of wealth per capita between 1700-25, 1725-50, and 1750-74, and Gallman's (1992, p. 95) estimate of the rate of growth of the real value of structures between 1774 and 1799. In effect we have assumed that the dwelling share of wealth and of structures remained constant over the period. 
Table 4

GDP Per Capita for Colonists and Slaves, Native Americans, and the Combined Population

$\begin{array}{rcccccc}\text { Year } & \begin{array}{c}\text { Colonists } \\ \text { and slaves }\end{array} & \begin{array}{c}\text { Native } \\ \text { American } \\ \text { Indians }\end{array} & \begin{array}{c}\text { Population Variant I } \\ \text { Indian } \\ \text { share }\end{array} & \begin{array}{c}\text { Combined } \\ \text { GDP per } \\ \text { Capita }\end{array} & \begin{array}{c}\text { Population Variant II } \\ \text { Indian } \\ \text { share }\end{array} & \begin{array}{c}\text { Combined } \\ \text { GDP per } \\ \text { Capita }\end{array} \\ 1720 & \$ 54.96 & \$ 35.49 & 0.30 & \$ 49.06 & 0.55 & 45.06 \\ 1740 & 51.65 & 35.12 & 0.12 & 49.70 & 0.28 & 47.80 \\ 1770 & 57.61 & 36.29 & 0.04 & 56.72 & 0.10 & 55.67 \\ 1800 & 58.98 & 34.72 & 0.01 & 58.64 & 0.04 & 58.23\end{array}$

Average Annual Rates of Change

$\begin{array}{lrrrrrr}1720-1770 & 0.09 & 0.05 & -3.9 & 0.29 & -3.3 & 042 \\ 1720-1800 & 0.09 & -0.03 & -3.7 & 0.22 & -3.3 & 0.32 \\ 1720-1740 & -0.31 & -0.05 & -4.5 & 0.07 & -3.6 & 0.30 \\ 1740-1770 & 0.37 & 0.11 & -3.4 & 0.44 & -3.1 & 0.51 \\ 1770-1800 & 0.08 & -0.15 & -3.4 & 0.11 & -3.3 & 0.15\end{array}$

Notes: Figures for colonists and slaves are from Table 2. The assumptions used to make the conjectures for Native Americans are described in the text. Given the method of estimation, the per capita value for Indians does not change with a change in the size of the Indian population. The combined figures do change as they are weighted averages of the per capita values for colonists and slaves and values for Indians, the weights being population shares.

The Indian population figures underlying the calculations are from Wood (1989, table 1) . We have interpolated where necessary assuming constant rates of growth between figures reported by Wood. The figures used in Var. I included those Indians in NC and SC east of the mountains plus the Creeks in Georgia and Alabama. The Var. II figures include those in Var. I plus the Cherokee, Choctaw and Chickasaw. We have put the share of the Indian population aged 10 and over at 76 percent in all years. The figures were based on reports made in 1703, 1708 and 1725, covering 350 Indians in the first case, 1,400 in the second and 4,002 in the third (Morgan 19, p. 144 and Klingberg, 1939, p. 496). We used the average of the three observations.

Evidence from Oglethorpe's expedition against St. Augustine indicates that the value of an Indian diet may have been as low as 30 percent that of a male colonist (CRSC, vol. II, pp.175-201). This may indicate that Indians were expected to forage for much of their food while on these expeditions. We have put the relative value at 75 percent, thereby assuming that the value of the Indians diet was no less valuable then that of slaves. Had we instead assumed that the Indian diet had been only 30 percent that of a free colonist, per capita GDP for Indians would have been only \$16 and would have risen at about the same rate as shown in this table. GDP per capita for the combined population would have been much lower in 1720 but unchanged in 1800 and so growth would have been noticeably faster $(0.37$ percent per year between 1720 and 1800). 